\title{
Thyroid function tests in amyloid goitre
}

\author{
P. Duhra and J. Cassar
}

West Middlesex University Hospital, Isleworth, Middlesex TW7 6AF, UK.

\begin{abstract}
Summary: We present two patients wth amyloid goitre due to primary systemic amyloidosis which was confirmed at post-mortem. Both were clinically euthyroid but had hyperthyroxinaemia and other thyroid function tests suggestive of thyrotoxicosis.
\end{abstract}

\section{Introduction}

Whereas minor amyloid infiltration of the thyroid gland is found in $50-80 \%$ of cases of generalized amyloidosis, ${ }^{1}$ the induction of a goitre by amyloid invasion is rare. ${ }^{2}$ Amyloid is an inert substance ${ }^{3}$ and infiltration of the thyroid does not usually interfere with the endocrine function of the gland. ${ }^{4,5}$ In two previous reports of possible hyperthyroidism in amyloid goitre an elevated basal metabolic rate, on which the diagnosis of hyperthyroidism rested, could instead have been attributed to the underlying chronic inflammatory disease producing the secondary amyloidosis. ${ }^{6}$ Apart from these two reports thyroid over-activity has not been noted in amyloid goitre.

We describe two cases with amyloid goitre who were clinically euthyroid but had hyperthyroxinaemia.

\section{Case reports}

\section{Case 1}

A 50 year old manual worker presented in February 1984 with an enlarging cervical swelling, dysphagia for solids, change in voice, weight loss and feeling generally ill. Physical examination revealed a euthyroid man with pallor, a soft pitched voice and a large, diffuse, hard goitre. There was no cervical lymphadenopathy nor dysthyroid eye disease and apart from moderate hepatosplenomegaly the rest of the examination was normal.

Investigations showed a normochromic normocytic anaemia with haemoglobin $8.7 \mathrm{~g} / \mathrm{dl}$; mean corpuscular volume $86.4 \mathrm{fl}$; erythrocyte sedimentation rate $39 \mathrm{~mm}$ in one hour. Biochemical profile was normal except total protein $71 \mathrm{~g} / 1$, albumin $28 \mathrm{~g} / \mathrm{l}$, plasma bicarbonate $18 \mathrm{mmol} / 1$, urea

Correspondence: J. Cassar, Ph.D, M.D., F.R.C.P. Accepted: 21 September 1989
$25.9 \mathrm{mmol} / \mathrm{l}$, creatinine $519 \mu \mathrm{mol} / \mathrm{l}$. Creatinine clearance was $12 \mathrm{ml} / \mathrm{min}$ and urinary protein excretion $0.3 \mathrm{~g} / 24$ hours.

Assessment of thyroid function disclosed a serum free thyroxine (FT4) of $32.5 \mathrm{pmol} / 1$ (NR $8.8-23)$, thyrotrophin releasing hormone (TRH) test showed thyroid stimulating hormone (TSH) values of $1.2,0.6,0.6 \mathrm{mU} / 1$ taken at time $0,30,60$ minutes after intravenous TRH bolus.

A technetium thyroid scan showed generalized thyroid enlargement with homogenous distribution of radiaoactivity. The overall technetium uptake was $5.1 \%$ of the dose at 20 minutes (normal upper level $3.5 \%$ ).

Serum TSH receptor antibody activity was determined using the Rapoport bioassay which utilizes human thyroid cells in culture. The thyroid stimulating antibody level was 18 bovine TSH equivalents per $\mathrm{ml}$ (normal range under 2.8). Thyroglobin and microsomal antibodies were undetectable in the serum.

Carbimazole therapy was introduced in April 1984 and FT4 three months later was reduced to $7.5 \mathrm{pmol} / \mathrm{l}$. In August 1984 carbimazole was inadvertently discontinued for 10 days and FT4, measured on the tenth day, had risen to $77.0 \mathrm{pmol} / \mathrm{l}$. Carbimazole was promptly recommenced. Serum immunoelectrophoresis showed a paraprotein, typed as IgG Kappa. Serum immunoglobulins were assayed: IgG $28 \mathrm{~g} / \mathrm{l}$ (NR 5.3-16.5); IgA $0.2 \mathrm{~g} / 1$ (NR 0.8-4.0) and IgM $0.3 \mathrm{~g} / 1$ (NR 0.5-2.0). A skeletal survey showed no lytic defects typical of multiple myeloma. A bone marrow aspirate contained $15 \%$ plasma cells with many abnormal forms.

A thyroid needle biopsy showed widely separated thyroid follicles some of which were filled with colloid. The thyroid stroma stained with congo red exhibited the characteristic apple-green birefringence of amyloid under polarized light. A renal biopsy performed in March 1985 confirmed the diagnosis. By February 1985 he had progressed to end-stage renal failure necessitating 
haemodialysis, and underwent a total thyroidectomy in April 1985 for relief of severe dysphagia. A pale, hard thyroid gland weighing 167 grammes was removed. There was gross amyloid infiltration accounting for approximately $90 \%$ of the thyroid mass. In addition to separating individual follicles, amyloid had obliterated many capillaries by invasion of their wall.

The follicles were atrophic with no hypertrophy of the follicular cells, and the only evidence of thyroid hyperactivity was some papillary infolding and scanty colloid. There was no significant cellular infiltration of the interstitium. He developed rapidly worsening cardiac failure and died 3 weeks after thyroidectomy. Necropsy revealed cardiac failure due to amyloid invasion of the heart as the main cause of death. There was widespread AL amyloid deposition and no evidence of any underlying chronic inflammatory disease.

\section{Case 2}

This patient was a school secretary and was first seen in 1950 when she was 40 years old. She had had a goitre since the age of 12 which on examination was multinodular. She was clinically euthyroid. In 1978 she was seen again because of onset of atrial fibrillation. Total T4 was $140 \mathrm{pmol} / 1$ (NR 60-150). Total triiodothyronine (T3) was $2.69 \mathrm{nmol} / \mathrm{l}$. (NR $1.23-3.07)$. Over the years $(1978-1982)$ her total T4 fluctuated between 136 to $190 \mathrm{nmol} / \mathrm{l}(n=14$, mean 162). Free T4 (1982-1984) fluctuated between 17.7 to $26.7 \mathrm{pmol} / \mathrm{l}$ ( $n=13$, mean 21.7 , NR $8.8-23)$. T3 was always within normal limits $(n=15)$, except on one occasion. Thyroid antibodies were negative. During a therapeutic trial of carbimazole at a dose of $15 \mathrm{mg} /$ day between July to November 1985 she quickly became hypothyroid with a free T4 down to $6.8 \mathrm{pmol} / \mathrm{l}$. TSH at this stage was $2.4 \mathrm{mU} / 1$ (NR 0-5.5). Also at her last visit to the clinic free T4 was $7.6 \mathrm{pmol} / \mathrm{l}$ and TSH $1.3 \mathrm{mU} / \mathrm{l}$. A TRH test was carried out in 1981 and TSH response was basal $5.2 \mathrm{mU} / 1,30$ minutes $5.1 \mathrm{mU} / \mathrm{l}$, 60 minutes $4.7 \mathrm{mU} / \mathrm{l}$. This was repeated in 1985 and on this occasion TSH levels were basal $0.9 \mathrm{mU} / 1,30$ minutes $1.2 \mathrm{mU} / 1,60$ minutes $1.3 \mathrm{mU} / 1$. Basal TSH levels between 1983 to 1986 were between 1.3 to $3 \mathrm{mU} / \mathrm{l}$. Thyroid stimulating immunoglobulin levels were within normal limits.

In May 1987 she complained of malaise and on examination she had generalized oedema but was clinically euthyroid. Urinalysis showed ++++ proteinuria, full blood count was normal, blood urea $7.9 \mathrm{mmol} / \mathrm{l}$, creatinine $96 \mu \mathrm{mol} / 1,24$ hour urine protein was $3.6 \mathrm{~g}$. No Bence Jones proteins were noted in the urine. Serum albumin was $17 \mathrm{~g} / 1$. Renal biopsy showed features of amyloidosis. Plasma protein electrophoresis did not show paraproteinaemia.
Trephine biopsy revealed an excess of mononuclear cells staining positively for immunoglobulin lambda light chains. Only some cells were recognizably plasmacytoid. Free T4 was $8.7 \mathrm{pmol} / \mathrm{l}$, TSH $0.6 \mathrm{mU} / 1$.

There was a rapid deterioration in her clincial state and she died 7 weeks after admission. Postmortem confirmed the diagnosis of $A L$ amyloidosis. There was amyloid in the thyroid, adrenal and pancreas. The thyroid weighed $360 \mathrm{~g}$. On section there were multiple nodules without cystic change or haemorrhage. Histology showed amyloidosis of follicular basement membranes, vessels, connective tissue septa and capsule.

\section{Discussion}

The presence of minor amyloid deposits in thyroid gland in systemic amyloidosis was first recorded in 1855 by Ven Rekitansky. Greater amyloid invasion of the thyroid, sufficient to produce a clinically detectable enlargement, was described by Von Beckman in 1858 .

Amyloid goitre usually manifests clinically as a rapidly enlarging cervical swelling with dysphagia, hoarseness of voice and dyspnoea, due to compression of local structures. There may be additional symptoms related to amyloid deposition in other organs. The goitre is firm to hard in consistency and this together with its rapid growth usually suggests malignancy ${ }^{7}$ and this suspicion may be strengthened by the finding of regional lymphadenopathy ${ }^{5}$ also due to amyloid invasion. The correct diagnosis is only revealed after thyroidectomy but in some cases a needle biopsy of the thyroid has satisfactorily established the diagnosis. ${ }^{8}$

Histologically, the thyroid parenchyma is virtually replaced by amyloid, the follicles are distorted, containing scanty colloid and their lining epithelium is flattened. ${ }^{9}$ The lumen of blood vessels may be narrowed by infiltration of their wall with amyloid. Massive deposition of amyloid in the thyroid may increase its size from five to ten times normal, and its weight from 150 to 250 grammes. The heaviest recorded weight being 573 grammes. $^{6}$

Despite such extensive amyloid infiltration the endocrine function of the gland is remarkably well preserved. In a review of 30 cases of amyloid goitre, Arien \& $\mathrm{Klein}^{6}$ found no instance of hypothyroidism. However, they did find two cases of possible hyperthyroidism, but this was based on an elevated basal metabolic rate which could instead be attributed to the underlying chronic inflammatory disease. Jaimet ${ }^{10}$ claims to have described the first case of hypothyroidism in amyloid goitre and another possible case of 
hypothyroidism was described by Danovitch $e t$ $a l .{ }^{11}$ However, their conclusion hinged on inadequate thyroid function tests. In our opinion, thyroid dysfunction in amyloid goitre has not been convincingly demonstrated.

The observation that our patients were clinically euthyroid despite markedly elevated free $\mathrm{T} 4$ raises the interesting question regarding its pathogenesis. Although T3 is more potent than T4 the latter does possess intrinsic hormonal activity ${ }^{12}$ and its elevation alone can sustain thyrotoxicosis. ${ }^{13,14}$ The presence of a normal T3 in the above cases does not therefore fully account for the occurrence of clinical euthyroidism in the face of hyperthyroxinaemia. A more probable explanation is that there is partial peripheral resistance to the action of T4. The exact mechanism of this resistance is unclear ${ }^{15}$ but a defect in the intracellular transport of $\mathrm{T} 4^{16}$ or reduced intracellular T4 $5^{\prime}$ deiodination has been proposed. ${ }^{17}$

A normal T3 in the presence of an elevated T4 in the above cases may also be due to the euthyroid sick syndrome. ${ }^{18}$ In this condition the peripheral

\section{References}

1. Kennedy, J.S., Thomson, J.A. \& Buchanan, W.M. Amyloid in the thyroid. $Q J$ Med 1974, 169: 127-143.

2. Shapiro, S.T., Kohut, R.I. \& Potter, J.M. Amyloid goitre Arch Otolaryngol 1971, 93: 203.

3. Hind, C.R.K \& Pepys, M.B. Amyloidosis: classification and pathogenesis (1). Hospital Update 1984, 10: 593-598.

4. James, P.D. Amyloid goitre. J Clin Pathol 1972, 25: 683-688.

5. Kneebone, R.L., Greeff, H. \& Mannell, A. Amyloid goitre: A case report. $S$ Afr Med J 1984, 65: 931-932.

6. Arean, V.M. \& Klein, R.E. Amyloid goitre: Review of the literature and report of a case. Am J Clin Pathol 1961, 36: 341-355.

7. Amado, J.A., Palacios, S., Mazanos, J., Ondiviela, R., Casanova, D. \& Freijanes, J. Fast growing goitre as the first clinical manifestation of systemic amyloidosis. Postgrad Med $J$ 1982, 58: $171-172$.

8. Gharib, N. \& Goellner, J.R. Diagnosis of amyloidosis by fine needle aspiration biopsy of the thyroid. $N$ Engl J Med 1981, 305: 586

9. Walker, G.A. Amyloid goitre. Surg Gynecol Obstet 1942, 75: 374-378.

10. Jaimet, C.H. Amyloid goitre. Can Med Assoc J 1951, 64: 158-159.

11. Danovitch, G.M., Le Roith, D., Sobel, R. Sikuler, E. \& Straus, $R$. Amyloid goitre in familial mediterranean fever. Clin Endocrinol 1979, 11: 595-601. conversion of $\mathrm{T} 4$ to $\mathrm{T} 3$ is impaired by the presence of a non-thyroidal illness. ${ }^{19}$ In our patients generalized amyloid deposition and in the later stages, chronic renal failure and cardiac failure would adequately explain this syndrome. The possibility of a circulating factor interfering with the free T4 assay cannot be excluded.

There are several interesting features about these cases. Amyloid goitre is itself a rarity with only about 80 previously reported cases. ${ }^{7}$ To our knowledge these are the first cases of hyperthyroxinaemia in clinically euthyroid patients with amyloid goitre due to systemic amyloidosis.

\section{Acknowledgements}

We acknowledge the help of Mr J. Fleming, Dr G. Hughes, Dr S. Kane, Dr A. Knudsen, Dr M. Phillip and Dr P. Gower in looking after these patients. The TS Ab assays were carried out by Dr A MacGregor and Dr T. Weetman.

12. Ingbar, S.H. \& Braverman, L. Active form of the thyroid hormone. Ann Rev Med 1975, 26: 443-449.

13. Turner, T.G., Brownlie, B.E.W. \& Sadder, W.A. Does T4 toxicosis exist? Lancet 1975, i: 407-408.

14. Birkhaser, M., Busset, R., Burer, T. \& Burger, A. Diagnosis of hyperthyroidism when serum thyroxine alone is raised. Lancet 1977, ii: 53-56.

15. Borst, G.C., Eil, C. \& Burman, K.D. Euthyroid hyperthyroxinaemia. Ann Intern Med 1983, 98: 366-378.

16. Wortsman, J., Premachandra, B.N. \& Hays, I. Euthyroid hyperthyroxinaemia due to decreased intracellular transport of thyroxine. In: Program and abstracts of 57 th meeting of the American Thyroid Association. Worcester, Massachusetts, 1981.

17. Kleinnaus, N., Faber, J., Kanana, L., Schneer, J. \& Scheinfeld, M. Euthyroid hyperthyroxinaemia due to a generalised 5'-deiodinase defect. J Clin Endocrinol Metab 1988, 66: 684-688.

18. Wartofsky, L. \& Burman, K.D. Alterations in thyroid function in patients with systemic illness: the 'euthyroid sick syndrome'. Endocr Rev 1982, 3: 164-217.

19. Cavalieri, R.R. \& Rapoport, B. Impaired peripheral conversion of thyroxine to triiodothyronine. Ann Rev Med 1977, 28: $57-65$. 